\title{
The Relationship between Organizational Commitment and Job Satisfaction
}

\author{
Yeşim Avunduk (Corresponding author) \\ Faculty of Economic, Administrative and Social Sciences \\ Istanbul Ayvansaray University, Ayvansaray Cd. No:45 D:45, 34662 Fatih, Istanbul, Turkey \\ Tel: 90-212-444-7696Ｅ-mail: dryavunduk@gmail.com
}

Received: August 28, $2021 \quad$ Accepted: September 21, 2021

Published: September 28, 2021

doi:10.5296/jei.v7i2.18966 URL: https://doi.org/10.5296/jei.v7i2.18966

\begin{abstract}
The study aimed to determine the relationship between organizational commitment and job satisfaction of individuals working in the sports sector. The sample of the study consisted of a total of 496 people (375 males and 121 females), who were working in a private company operating in the sports sector in Istanbul, and selected by easy sampling method. In addition to the personal information form, the "Organizational Commitment Scale" developed by Meyer and Allen $(1984,1997)$ and adapted to Turkish by Boylu et al. (2007), and the Minnesota Job Satisfaction Scale, developed by Weiss et al. (1967) and adapted into Turkish by Baycan (1985) were used as data collection tools. Analyzes were analyzed using SPSS 22.0 package program. Independent t-test, ANOVA and Pearson Correlation analyses were performed to analyse the data. In addition, the analyzes were performed at a $95 \%$ confidence interval. Analysis results showed that there was a significant difference in the continuance commitment sub-dimension of individuals according to the gender variable. It was determined that there was a significant difference in both the job satisfaction levels and the affective and normative commitment levels of the individuals according to their welfare status. Moreover, it was determined that there was a significant difference in all sub-dimensions of the job satisfaction scale and in all sub-dimensions of the organizational commitment scale according to the educational status of the participants. As a result, it was determined that there was a positive and moderate relationship between "Affective Commitment" and "Continuance Commitment" and "Internal Satisfaction" and "External Satisfaction". Another result, it was determined that the organizational commitment and job satisfaction levels of the individuals differed according to their socio-demographic characteristics, and as the affective and continuance commitment of the individuals increased, their job satisfaction increased.
\end{abstract}


Keywords: Sports sector, Organizational commitment, Job satisfaction

\section{Introduction}

Today, the increasing interest in the concepts of organizational commitment and job satisfaction has brought many studies on this subject. Both the interaction of these concepts with each other and their interactions with other organizational factors diversifies researchers' studies and the results of studies on these concepts in different sectors (Yenihan, 2014). In this context, organizational commitment concept is the psychological integration of the employee with the organization they work for, the assimilation of the goals and objectives of the organization, and the desire of the person to stay in the organization in this direction (Gül et al., 2008: Çarıçıı \& Çelikkol, 2009). Organizational commitment is defined in different ways like an attitude that associates the identity of the employee with the organization, a process in which the goals of the organization are in harmony with the goals of the employee, the behaviour displayed as a result of the perception of the benefits of absorbing to the goals of the organization and the costs of leaving the organization, the situation created by the normative pressure to absorb the goals of the organization (Meyer \& Allen, 1997; Efeoğlu \& Özgen, 2007).

Organizational commitment also means complying with the aims and objectives of the organization, organizational principles, rules and norms and volunteering for their survival. Employees exhibit two types of behaviour against organizational rules, one of them is "compliance" behaviour and the other is "attachment" behaviour. While employees' fulfilment of organizational rules without adopting them is a "compliance behaviour", their voluntary adoption of organizational rules, goals and objectives, all organizational interests and doing what is necessary is "attachment behaviour" (Tutar, 2007). In other words, there are two important concepts on the basis of organizational commitment. One of them is loyalty and the other one is the tendency to stay organized. Loyalty means identifying with an organization and feeling affective responsibility, based on a sense of duty and responsibility. It emerges as an important variable in the relationship between the values and expectations of the employee and the decision to stay or leave the organization. Accordingly, while loyalty decreases with leaving the organization, it increases in a positive and rewarding environment. The tendency to stay in the organization can be explained as an affective intimacy and the employee's intention to remain a member of the organization. The individual decides to stay or leave the organization by calculating the perceived benefit of staying in the organization (Uygur, 2007). Organizational commitment has three dimensions. These are, respectively, affective commitment, continuance commitment and normative commitment. Affective Commitment occurs as a result of the harmony between individual and organizational values that make employees happy for being a member of the organization. Continuance Commitment is about the employee's perception of the costs associated with leaving the organization. Work-related costs such as time and effort spent, and non-job costs such as relocation costs are issues that the employee takes into account in getting attached to the organization. Affective commitment means the employee's affective attachment to the organization, identification with the organization and voluntary participation in the organization (Karcığlu \& Çelik, 2012). Normative commitment is a moral duty as well as a 
positive emotional commitment. Therefore, individuals with high commitment want to continue working in their jobs, while those with strong and normative commitment think it is right to stay at work. (Wieselsberger, 2004: Altınöz et al., 2011). The common idea of numerous studies on organizational commitment is that it attracts attention as a situation that leads to attitudes and behaviours that have positive results for both the organization and the individual (Koç, 2009).

The concept of job satisfaction plays a decisive role in the employee's attitude towards the job. Job satisfaction is the employee's achievement of job expectations or achieving good job results. In other words, it is how the individual feels towards the job. The individual may show a positive or negative attitude towards the job. While job satisfaction is evaluated as a positive attitude, job dissatisfaction is evaluated as a negative attitude (Vroom, 1978; Demirel \& Özçınar, 2009). In other words, job satisfaction is a personal evaluation of the job conditions or the results obtained from the job. Job satisfaction consists of internal reactions that an individual develops against perceptions of the processed job and job conditions by passing through the system of norms, values and expectations (Kitapç1 et al., 2013). The most important feature of job satisfaction is that it is an affective concept rather than a mental one. Since it is personal, the most important thing the manager can do is to help the employees to reach an optimum level of satisfaction (Karcioğlu et al., 2009). Job satisfaction is divided into two as internal and external job satisfaction (Landy \& Conte, 2010). Internal job satisfaction is related to the central or internal aspects of the work that individuals do. Usage of skills, responsibility, creativity, helping others, freedom and success can be given as examples. External job satisfaction, on the other hand, is related to the external aspects of work-related tasks. As examples of external job satisfaction, promotion opportunities, wages, corporate policy and practices, working conditions, management approach and job guarantee can be given (Biçkes et al., 2014). Job satisfaction has a more holistic structure that includes satisfaction with many factors such as job, wage, career opportunity, working conditions, organizational practices. Job satisfaction is more passive; organizational commitment has a more active and behavioural meaning. In various studies on the relationship between job satisfaction and organizational commitment, it was concluded that there was a positive relationship between these two attitudes (Stroh et al., 2002, Aktay, 2010; Hoş \& Oksay, 2015). In this context, the study aimed to examine the relationship between organizational commitment and job satisfaction of individuals working in the sports sector.

\section{Method}

\subsection{Research Method}

The relational model, one of the survey models, was used in the research. In the relational screening method, the degree of change between two or more variables is tried to be determined (Creswell, 2017).

\subsection{Research Group}

The sample of the study consisted of 496 people, 375 males $\left(\right.$ Mean $\left._{\text {age }}=38.18 \pm 7.71\right)$ and 121 females $\left(\right.$ Mean $\left._{\mathrm{age}}=33.61 \pm 7.26\right)$, who worked for a private company operating in the sports 
sector and were selected by easy sampling method. The easy sampling method can be defined as the easiest way to reach the people in the sample (Patton, 2005).

\subsection{Data Collection Tools}

\subsubsection{Personal Information Form}

The "Personal Information Form" prepared by the researcher was used to determine the gender, age, marital status, welfare status, workplace conditions and working hours of the participants.

\subsubsection{Organizational Commitment Scale}

The "Organizational Commitment Scale" developed by Meyer and Allen $(1984,1997)$ and adapted into Turkish by Boylu et al. (2007) was used to determine the organizational commitment of the employees. The scale consisted of 18 items and 3 sub-dimensions. Sub-dimensions, respectively; Continuance Commitment (6 Items), Affective Commitment (6 Items) and Normative Commitment (6 Items). The scale was 5-Likert type and answered as $(1=$ Strongly Disagree; $5=$ Strongly Agree). The validity and reliability tests of this scale were also carried out within the scope of this study. The Cronbach Alpha coefficient calculated for the overall scale is 0.86 . The coefficients calculated for the sub-dimensions are $0.81,0.75$ and 0.82 , respectively.

\subsubsection{Minnesota Job Satisfaction Scale}

The Minnesota Job Satisfaction Scale, developed by Weiss et al. (1967) and adapted into Turkish by Baycan (1985), was used in the study. The scale consisted of 20 items and 2 sub-dimensions. The sub-dimensions were Internal Satisfaction (12 items) and External Satisfaction (8 items). The scale was 5-Likert type and answered as $1=$ Not Pleased; $5=$ Very Pleased. The Cronbach Alpha reliability coefficient calculated for this scale in general was calculated as 0.81 . In the sub-dimensions, it was calculated as 0.80 for internal satisfaction and 0.83 for external satisfaction.

\subsection{Data Analysis}

The research was analyzed in the SPSS package program. The tests to be used in the analysis of the research data were decided according to the skewness and kurtosis values. As seen in Table 2, the data is in the range of -2 to +2 . According to George and Mallery (2010), skewness and kurtosis values between +2 and -2 are sufficient for the normal distribution of the data. Therefore, assuming that the research data showed a normal distribution, the research data were analyzed with $\mathrm{t}$ test, ANOVA and Pearson Correlation test for independent samples. The data were evaluated at a significance level of 0.05 with a $95 \%$ confidence interval. 


\section{Findings}

Table 1. Distribution of personal information of participants

\begin{tabular}{|c|c|c|c|}
\hline Variables & & $\mathbf{F}$ & $\%$ \\
\hline \multirow{3}{*}{ Gender } & Female & 121 & 24.4 \\
\hline & Male & 375 & 75.6 \\
\hline & Total & 496 & 100 \\
\hline \multirow{3}{*}{ Marital Status } & Married & 395 & 79.6 \\
\hline & Single & 101 & 20.4 \\
\hline & Total & 496 & 100 \\
\hline \multirow{4}{*}{ Welfare Status } & Low & 49 & 9.9 \\
\hline & Normal & 390 & 78.6 \\
\hline & High & 57 & 11.5 \\
\hline & Total & 496 & 100 \\
\hline \multirow{4}{*}{ Educational Status } & Highschool & 149 & 30.0 \\
\hline & University & 320 & 64.5 \\
\hline & Postgraduate & 27 & 5.4 \\
\hline & Total & 496 & 100 \\
\hline \multirow{5}{*}{ Working Periods } & Less than 1 year & 39 & 7.9 \\
\hline & 1-3 Years & 83 & 67 \\
\hline & 4-6 Years & 67 & 13.5 \\
\hline & 7 years and more & 307 & 61.9 \\
\hline & Total & 496 & 100 \\
\hline \multirow{4}{*}{ Working Conditions } & Sufficient & 270 & 54.4 \\
\hline & Partially & 194 & 39.1 \\
\hline & Insufficient & 32 & 6.5 \\
\hline & Total & 496 & 100 \\
\hline
\end{tabular}

The distribution of the personal information of the participants given in Table 1. According to the analysis results, it was determined that $75.6 \%$ of the participants were "Male", $79.6 \%$ "Married", $78.6 \%$ of them was "Normal" regarding welfare status, 64.5\% "University" 
graduates. While $61.9 \%$ was working for "7 years and more" in this workplace, $54.4 \%$ of them had "Sufficient" working conditions at the workplace.

Table 2. Distribution of scale scores

\begin{tabular}{|l|l|l|l|l|l|l|l|}
\hline \multicolumn{2}{|l|}{ Sub-Dimensions } & Items & $\mathbf{n}$ & Mean & Sd. & Skewness & Kurtosis \\
\hline \multirow{3}{*}{$\begin{array}{l}\text { Organizational } \\
\text { Commitment Scale }\end{array}$} & Affective Commitment & 6 & 496 & 1.72 & 0.72 & 1.39 & 1.01 \\
\cline { 2 - 8 } & Normative Commitment & 6 & 496 & 3.13 & 0.68 & 0.55 & 0.36 \\
\cline { 2 - 8 } & Continuance Commitment & 6 & 496 & 2.39 & 0.60 & 0.51 & 1.18 \\
\hline \multirow{2}{*}{ Job Satisfaction Scale } & Internal Satisfaction & 12 & 496 & 2.07 & 0.62 & 1.08 & 1.69 \\
\cline { 2 - 8 } & External Satisfaction & 8 & 496 & 2.46 & 0.76 & 0.62 & 0.48 \\
\hline
\end{tabular}

Table 2 showed the mean scores of the participants, from their scale scores. According to the analysis results, it was determined that the highest mean was in the "Normative Commitment" (3.13) sub-dimension, and the lowest mean was in the "Affective Commitment" (1.72) sub-dimension at the sub-dimensions level of organizational commitment scale. When the level of the sub-dimensions of the job satisfaction scale was examined, it was determined that the highest mean was in the "External Satisfaction" (2.46) sub-dimension and the lowest mean was in the "Internal Satisfaction" (2.07) sub-dimension.

Table 3. Independent t-test results of scale scores according to the gender variable

\begin{tabular}{|c|c|c|c|c|c|}
\hline & Gender & $\mathbf{n}$ & $\operatorname{Mean} \pm$ Sd. & $\mathbf{t}$ & $\mathbf{p}$ \\
\hline \multirow{2}{*}{ Affective Commitment } & Female & 121 & $1.80 \pm 0.80$ & \multirow{2}{*}{1.370} & \multirow{2}{*}{.171} \\
\hline & Male & 375 & $1.70 \pm 0.70$ & & \\
\hline \multirow{2}{*}{ Normative Commitment } & Female & 121 & $3.23 \pm 0.67$ & \multirow{2}{*}{1.819} & \multirow{2}{*}{.070} \\
\hline & Male & 375 & $3.10 \pm 0.68$ & & \\
\hline \multirow{2}{*}{ Continuance Commitment } & Female & 121 & $2.52 \pm 0.67$ & \multirow{2}{*}{2.689} & \multirow{2}{*}{$.007 *$} \\
\hline & Male & 375 & $2.35 \pm 0.58$ & & \\
\hline \multirow{2}{*}{ Internal Satisfaction } & Female & 121 & $2.14 \pm 0.75$ & \multirow{2}{*}{1.478} & \multirow{2}{*}{.140} \\
\hline & Male & 375 & $2.04 \pm 0.58$ & & \\
\hline \multirow{2}{*}{ External Satisfaction } & Female & 121 & $2.53 \pm 0.79$ & \multirow{2}{*}{1.174} & \multirow{2}{*}{.241} \\
\hline & Male & 375 & $2.44 \pm 0.75$ & & \\
\hline
\end{tabular}




\section{Macrothink}

Table 3 shows the t-test results of the research. According to the analysis results, it was found that there was a significant difference only in the "Continuance Commitment" sub-dimension of the organizational commitment scale $(\mathrm{p}<0.05)$. Females' continuance commitment levels were higher than males. It was determined that there was no significant difference between the job satisfaction of the individuals according to the gender variable $(\mathrm{p}>0.05)$.

Table 4. Independent t-test results on scale scores according to the welfare status variable

\begin{tabular}{|c|c|c|c|c|c|}
\hline & Welfare Status & $\mathbf{n}$ & $\operatorname{Mean} \pm$ Sd. & f & $\mathbf{p}$ \\
\hline \multirow{3}{*}{ Affective Commitment } & Low & 49 & $1.78 \pm 0.98$ & \multirow{3}{*}{5.775} & \multirow{3}{*}{$.003 *$} \\
\hline & Normal & 390 & $2.06 \pm 0.66$ & & \\
\hline & High & 57 & $1.71 \pm 0.79$ & & \\
\hline \multirow{3}{*}{ Normative Commitment } & Low & 49 & $2.91 \pm 0.69$ & \multirow{3}{*}{3.886} & \multirow{3}{*}{$.021 *$} \\
\hline & Normal & 390 & $3.31 \pm 0.67$ & & \\
\hline & High & 57 & $3.28 \pm 0.72$ & & \\
\hline \multirow{3}{*}{ Continuance Commitment } & Low & 49 & $2.47 \pm 0.77$ & \multirow{3}{*}{.826} & \multirow{3}{*}{.438} \\
\hline & Normal & 390 & $2.39 \pm 0.56$ & & \\
\hline & High & 57 & $2.32 \pm 0.69$ & & \\
\hline \multirow{3}{*}{ Internal Satisfaction } & Low & 49 & $2.47 \pm 0.85$ & \multirow{3}{*}{12.267} & \multirow{3}{*}{$.000 *$} \\
\hline & Normal & 390 & $2.03 \pm 0.53$ & & \\
\hline & High & 57 & $1.94 \pm 0.83$ & & \\
\hline \multirow{3}{*}{ External Satisfaction } & Low & 49 & $3.13 \pm 0.79$ & \multirow{3}{*}{22.958} & \multirow{3}{*}{$.000 *$} \\
\hline & Normal & 390 & $2.41 \pm 0.70$ & & \\
\hline & High & 57 & $2.27 \pm 0.90$ & & \\
\hline
\end{tabular}

In Table 4, the results of ANOVA analysis regarding the scale scores according to the welfare status of the individuals participating in the research were given. According to the analysis results, it was determined that there was a significant difference in the "Affective Commitment" and "Normative Commitment" sub-dimensions of the organizational commitment scale of the participants $(p<0.05)$. The mean scores of the participants with normal welfare status were higher than the scores of other individuals. Moreover, it was found that individuals with low well-being had higher levels of satisfaction in both internal and external satisfaction levels according to the high well-being of the participants $(p<0.05)$. 


\section{Macrothink}

Table 5. Independent t-test results on scale scores according to the educational status variable

\begin{tabular}{|c|c|c|c|c|c|}
\hline & Educational Status & $\mathbf{n}$ & $\operatorname{Mean} \pm$ Sd. & $\mathbf{F}$ & $\mathbf{p}$ \\
\hline \multirow{3}{*}{ Affective Commitment } & Highschool & 149 & $1.56 \pm 0.63$ & \multirow{3}{*}{6.028} & \multirow{3}{*}{$.003 *$} \\
\hline & University & 320 & $1.78 \pm 0.73$ & & \\
\hline & Postgraduate & 27 & $1.94 \pm 0.92$ & & \\
\hline \multirow{3}{*}{ Normative Commitment } & Highschool & 149 & $3.04 \pm 0.69$ & \multirow{3}{*}{3.524} & \multirow{3}{*}{$.003 *$} \\
\hline & University & 320 & $3.15 \pm 0.68$ & & \\
\hline & Postgraduate & 27 & $3.40 \pm 0.62$ & & \\
\hline \multirow{3}{*}{ Continuance Commitment } & Highschool & 149 & $2.24 \pm 0.62$ & \multirow{3}{*}{8.061} & \multirow{3}{*}{$.000 *$} \\
\hline & University & 320 & $2.44 \pm 0.58$ & & \\
\hline & Postgraduate & 27 & $2.63 \pm 0.64$ & & \\
\hline \multirow{3}{*}{ Internal Satisfaction } & Highschool & 149 & $1.92 \pm 0.60$ & \multirow{3}{*}{5.609} & \multirow{3}{*}{$.004 *$} \\
\hline & University & 320 & $2.13 \pm 0.63$ & & \\
\hline & Postgraduate & 27 & $2.23 \pm 0.69$ & & \\
\hline \multirow{3}{*}{ External Satisfaction } & Highschool & 149 & $2.26 \pm 0.77$ & \multirow{3}{*}{7.976} & \multirow{3}{*}{$.000 *$} \\
\hline & University & 320 & $2.53 \pm 0.70$ & & \\
\hline & Postgraduate & 27 & $2.72 \pm 0.88$ & & \\
\hline
\end{tabular}

In Table 5, the results of ANOVA analysis regarding the scale scores according to the educational status of the participants were given. According to the analysis results, it was determined that there was a statistically significant difference in all sub-dimensions of the organizational commitment scale of the participants $(p<0.05)$. The mean scores of individuals who continue their graduate education or postgraduate were higher than other individuals. Again, according to the educational status of the participants, it was determined that the scores of the individuals who continue or complete their graduate education were higher in both internal and external satisfaction levels $(\mathrm{p}<0.05)$. 
Table 6. Correlation analysis results between organizational commitment scale and job satisfaction scores

\begin{tabular}{|l|l|l|l|l|l|}
\hline & F1 & F2 & F3 & F4 & F5 \\
\hline Affective Commitment & 1 & & & & \\
\hline Normative Commitment & $.096^{*}$ & 1 & & & \\
\hline Continuance Commitment & $.615^{*}$ & $.335^{*}$ & 1 & & \\
\hline Internal Satisfaction & $.604^{*}$ & .001 & $.444^{*}$ & 1 & \\
\hline External Satisfaction & $.484^{*}$ & .043 & $.401^{*}$ & $.790^{* *}$ & 1 \\
\hline
\end{tabular}

In Table 6, Pearson correlation analysis was performed to determine the relationship between the sub-dimensions of the organizational commitment scale and the sub-dimensions of the job satisfaction scales. According to the analysis results, it was determined that there was a positive and moderate relationship between "Affective Commitment" and "Continuance Commitment", and "Internal Satisfaction" and "External Satisfaction" of the organizational commitment scale.

\section{Discussion}

When the job satisfaction levels of the individuals were examined according to their gender, the job satisfaction levels of the participants did not differ according to their gender. Studies on job satisfaction performed to determine whether the level of job satisfaction varied by gender. In this context, in the study by Koç and Yazıcıoğlu (2011), Doğan and Akandere (2019), Dumangöz (2021), which examined the relationship in job satisfaction, it was determined that the job satisfaction levels of individuals according to the gender variable did not differ. When the organizational commitment levels of females and males were examined, a significant difference was found in the "Continuance Commitment" sub-dimension. In other words, female continuance commitment sub-dimension scores were higher than male's scores. In the study conducted by Bozkurt and Yurt (2013) to determine the organizational commitment levels of academicians, it was determined that there was no statistically significant difference according to the gender variable. In the study examining the relationship between perceived organizational commitment and organizational cynicism by Altınöz et al. (2011), it was determined that there was no significant difference in the organizational commitment levels of the participants according to their gender.

When the organizational commitment levels of the participants were examined according to their welfare status, it was determined that there was a statistically significant difference in the sub-dimensions of "Affective Commitment" and "Normative Commitment". In other words, individuals with normal welfare status had higher affective and normative commitment levels compared to other individuals. It was determined that there was a statistically significant difference between the job satisfaction levels of individuals according to their welfare status. In other words, it was determined that there was a significant 
difference in both internal and external satisfaction levels according to the welfare of the participants.

A statistically significant difference was found in both internal and external satisfaction levels of individuals according to their educational status. In other words, individuals who continue or complete their postgraduate education had higher levels of both internal and external satisfaction compared to other individuals. When the studies in the literature were examined, the results of the study conducted by Koç and Yazıcıoglu (2011) did not match with the results of this study. When the organizational commitment levels of the participants were examined according to their educational status, it was determined that there was a statistically significant difference. In other words, it was determined that the organizational commitment levels of the individuals studying at postgraduate were higher. In the study conducted by Taşkın and Dilek (2010) on organizational trust and organizational commitment, it was determined that there was a statistically significant difference between Affective commitment and continuance commitment. In the study examining the relationship between perceived organizational commitment and organizational cynicism by Altınöz et al. (2011), it has been determined that organizational commitment differs according to educational status.

\section{Conclusion}

As a result of the Pearson correlation analysis performed to determine the relationship between the organizational commitment scale and the job satisfaction scale, it was found that the organizational commitment scale had a positive and moderate relationship between "Affective Commitment" and "Continuance Commitment" and "Internal Satisfaction" and "External Satisfaction". Thus, in a study by Hoş and Oksay (2015) examining nurses' organizational commitment and job satisfaction, a moderate and positive relationship was found between organizational commitment and job satisfaction. Moreover, in the studies conducted by May et al. (2002); Testa (2001); Gade et al. (2003); Rowden (2000); Finegan (2000), and Örücü (2010), It was found that there is a positive and significant relationship between job satisfaction and organizational commitment.

As a result, it was determined that there was no difference between the job satisfaction levels of the participants according to gender, but the continuance commitment scores of the female were higher. It was observed that the participants with normal well-being status had higher scores of normative commitment, affective commitment, inner satisfaction, and external satisfaction. Moreover, it was determined that individuals who continue or complete their postgraduate education had higher levels of both organizational commitment and job satisfaction. It was determined that there was a positive and moderate relationship between "Affective Commitment" and "Continuance Commitment" and "Internal Satisfaction" and "External Satisfaction" of the organizational commitment scale.

\section{References}

Aktay, D. D. (2010). İş tatmini ve örgütsel bağlılık arasındaki ilişki ve askeri hastanede bir uygulama (İstanbul Üniversitesi Sosyal Bilimler Enstitüsü Hastane ve Sağlık Kuruluşlarında Yönetim Anabilim Dalı Yüksek Lisans Tezi, İstanbul). 
Altınöz, M., Çöp, S., \& Sığındı, T. (2011). Algılanan örgütsel bağlılık ve örgütsel sinizm ilişkisi: ankara'daki dört ve beş yıldızlı konaklama işletmeleri üzerine bir araştırma S.Ü.İ.I.B.F. Sosyal ve Ekonomik Araştırmalar Dergisi, 11(21), 286-341.

Baycan, F. A. (1985). Farklı gruplarda çalışan kişilerde iş doyumunun bazı yönlerinin analizi (Yayınlanmamış Bilim Uzmanlığı Tezi, Boğaziçi Üniversitesi, İstanbul).

Biçkes, D. M., Yılmaz, C., Demirtaş, Ö., \& Uğur, A. (2014). Duygusal emek ile iş tatmini arasındaki ilişkide psikolojik sermayenin aracılık rolü: Bir alan çalışması. Eskişehir Osmangazi Üniversitesi İIBF Dergisi, 9(2), 97-121.

Boylu, Y., Pelit, E., \& Güçer, E. (2007). akademisyenlerin örgütsel bağl1lık düzeyleri üzerine bir araştırma. Finans Politik \& Ekonomik Yorumlar, 44(511), 55-74.

Bozkurt, Ö., \& Yurt, İ. (2013). Akademisyenlerin örgütsel bağlılık düzeylerini belirlemeye yönelik bir araştırma. Yönetim Bilimleri Dergisi, 11(22), 121-139.

Çarıkçı, İ. H., \& Çelikkol, Ö. (2009). İş-aile çatışmasının örgütsel bağlılık ve işten ayrılma niyetine etkisi. Süleyman Demirel Üniversitesi Sosyal Bilimler Enstitüsü Dergisi, 1(9), 153-170.

Cresswell, J. W. (2017). Research Design. Qualitative, Quantitative and Mixed Methods Approaches.

Demirel, Y., \& Özçınar, F. M. (2009). örgütsel vatandaşlık davranışının iş tatmini üzerine etkisi: Farklı sektörlere yönelik bir araştırma. İktisadi ve İdari Bilimler Dergisi, 23(1), 130-145.

Doğan, M., \& Akdere, M. (2019). Research on job satisfaction and burnout levels of taekwondo coaches. Spormetre, 17(2), 154-162. https://doi.org/10.33689/spormetre.452334

Dumangöz, P. D. (2021). Investigation of Job Satisfaction Levels of Tennis Coaches Who Work In Higher Education Institutions According to Personal Variables. Journal of Educational Issues, 7(1), 282-295. https://doi.org/10.5296/jei.v7i1.18484

Efeoğlu, İ. E., \& Özgen, H. (2007). İş-aile yaşam çatışmasının iş stresi, iş doyumu ve örgütsel bağl1lık üzerindeki etkileri: ilaç sektöründe bir araştırma. Ç.Ü. Sosyal Bilimler Enstitüsü Dergisi, 16(2), 237-254.

Finegan, E. J (2000). The Impact of Person and Organizational Values on Organizational Commitment. Journal of Occupational and Organizational Psychology, 73, 149-169. https://doi.org/10.1348/096317900166958

Gade, P. A., Ronald, B. T., \& Walter, R. S. (2003). The measurement and consequences of military organizational commitment in soldiers and spouses. Military Psychology, 15(3), 191-207. https://doi.org/10.1207/S15327876MP1503_03

George, D., \& Mallery, M. (2010). SPSS for windows step by step: A simple guide and reference (17.0 update, 10th ed.). Boston: Pearson. 
Gül, H., Oktay, E., \& Gökçe, H. (2008). İş tatmini, stres, örgütsel bağlılık, isten ayrılma niyeti ve performans arasındaki ilişkiler: Sağlık sektöründe bir uygulama. Akademik Bakış Uluslararası Hakemli Sosyal Bilimler E Dergisi, 15, 72-82.

Hoş, C., \& Oksay, A. (2015). hemşirelerde örgütsel bağlılık ile iş tatmini ilişkisi. Süleyman Demirel Üniversitesi İktisadi ve İdari Bilimler Fakültesi Dergisi, 20(4), 1-24.

Karcıoğlu, F., \& Çelik, Ü. H. (2012). mobbing (yıldırma) ve örgütsel bağlılığa etkisi. Atatürk Üniversitesi İktisadi ve İdari Bilimler Dergisi, 26(1), 59-74.

Karcıoğlu, F., Timuroğlu, K., \& Çınar, O. (2009). örgütsel iletişim ve iş tatmini ilişkisi bir uygulama. Yönetim, 20(63), 59-76.

Kitapçı, H., Kaynak, R., \& Ökten, S. S. (2013). güçlendirmenin iş tatmini ve işten ayrılma niyetine etkisi: kamu ve özel sektörde mukayeseli bir araştırma. International Review of Economics and Management, 1(1), 49-73. https://doi.org/10.18825/iremjournal.109059

Koç, H. (2009). Örgütsel bağlilik ve sadakat ilişkisi. Elektronik Sosyal Bilimler Dergisi, 8(28), 200-211.

Koç, H., \& Yazıcıŏ̆lu, İ. (2011). Yöneticiye duyulan güven ile iş tatmini arasındaki ilişki: Kamu ve özel sektör karşılaştırması. Doğuş Üniversitesi Dergisi, 12(1), 46-57. https://doi.org/ 10.31671/dogus.2019.150

Landy, F. J., \& Conte, J. M. (2010). Work in The 21st Century an Introduction to Industrial and Organizational Psychology. California: Wiley-Blackwell.

May, T., Yeuk-Mui, M. K., \& Stephen J. F. (2002). Organizational and occupational commitment: Konowledge workers in large corporations. Journal of Management Studies, 39(6), 775-801. https://doi.org/10.1111/1467-6486.00311

Meyer, J. P., \& Allen, N. J. (1984). Testing the Side Bet Theroy of Organizational Commitment: Some Methodological Considerations. Journal of Applied Psychology, 69, 372-378. https://doi.org/10.1037/0021-9010.69.3.372

Meyer, J., \& Allen, N. (1997). Commitment in the Workplace. Thousand Oaks SAGE Publications, CA.

Örücü, E., Kılıç, R., \& Şimşir, S. (2010). Organizasyonlarda iş tatmini uygulamaları ve örgütsel bağlılığa etkisi üzerine bir araştırma. Yönetim ve Ekonomi Araştırmaları Dergisi, $8(13), 1-14$.

Patton, M. Q. (2005). Qualitative Research. New York: John Wiley \& Sons, Ltd.

Rowden, R. W. (2000). The relationship between charismatic leadership behaviours and organizational commitment. The Leadership \& Organization Development Journal, 21(1), 30-35. https://doi.org/10.1108/01437730010310712

Taşkın, F., \& Dilek, R. (2010). Örgütsel güven ve örgütsel bağl1lık üzerine bir alan araştırmas1. Organizasyon ve Yönetim Bilimleri Dergisi, 2(1), 37-46. 


\section{Macrothink

Testa, M. R. (2001). Organizational commitment, job satisfaction, and effort in the service environment. The Journal of Psychology, 135(2), 226-236. https://doi.org/10.1080/00223980 109603693

Tutar, H. (2007). Erzurum'da devlet ve özel hastanelerde çalışan sağlık personelinin işlem adaleti, iş tatmini ve duygusal bağlılık durumlarının incelenmesi. Süleyman Demirel Üniversitesi İktisadi ve İdari Bilimler Fakültesi, 12(3), 97-120.

Uygur, A. (2007). Örgütsel bağl1lık ile işgören performansı ilişkisini incelemeye yönelik bir alan araştırması. Ticaret ve Turizm Eğitim Fakültesi Dergisi, 1, 71-85.

Vroom, V. H. (1978). Work and Motivation. Wiley Eastern, New Delhi.

Weiss, D. J, Dawis, R. V., England, G. W., \& Lofquist, L. H. (1967). Minnesota Satisfaction Questionnaire-Short Form (Database Record). APA PsycTests.

Wieselsberger, K. (2004). The Psychological Contract is Dead, Long Live the Psychological Contract: Issues of Talent Management and Retention in the Context of the New Employment Relationship. London School of Economics, London.

Yenihan, B. (2014). Örgütsel bağlılık ve iş tatmini arasındaki ilişki. Karabük Üniversitesi Sosyal Bilimler Enstitüsü Dergisi, 4(2), 170-178. https://doi.org/10.14230/joiss80

\section{Copyright Disclaimer}

Copyright for this article is retained by the author(s), with first publication rights granted to the journal.

This is an open-access article distributed under the terms and conditions of the Creative Commons Attribution license (http://creativecommons.org/licenses/by/3.0/). 